\title{
The Great Depression in Canada and the United States: A Neoclassical Perspective
}

\author{
Pedro Amaral and James C. MacGee
}

Canada suffered a major depression from 1929 to 1939. In terms of output, it was similar in both timing and magnitude to the Great Depression in the United States. This has led some to conclude that the two episodes were essentially identical and share a common explanation (Betts, Bordo, and Redish 1996; Siklos 2002).

The declines in output, productivity, and employment were very similar. However, the recoveries, though being very similar in terms of output, were different in two important respects. In Canada, productivity did not return to trend as it did in the United States, whereas employment recovered more in Canada than in the United States.

The slow recovery of output per adult in the United States, despite the full recovery of productivity, was observed by Cole and Ohanian (1999) as a puzzle. (A revised version of the Cole-Ohanian paper appears as the second chapter in this volume.) Cole and Ohanian (2004) argue that cartelization and labor market policies can solve this puzzle. However, in Canada there is no puzzle because productivity did not return to trend. We find that Canada did not follow the policies that Cole and Ohanian argue gave rise to the incomplete recovery in the United States. Our conclusion is that Canadian output per adult was still 30 percent below trend in 1938 because productivity failed to return to trend.

Trade accounted for roughly half of Canadian output. A conventional view is that Canada imported the Great Depression via a collapse in the terms of trade. But we find that the effects of terms of trade shocks on output are negligible.

A voluminous body of research has developed on the role of deflation in the Great Depression. We consider four standard transmission mechanisms that operate through either the credit market or the labor market. We find these 
stories fail to account for the ten-year Canadian Depression. These stories are not consistent with Canada's 1920-22 deflation, which was similar in magnitude to its 1929-33 deflation. Also, these stories are inconsistent with Canada's slow recovery.

Given our findings, we conclude that any successful theory of the tenyear Canadian Depression should explain why productivity was so far below trend for so long. Any explanation should also be consistent with the fact that productivity recovered in the United States.

\section{Data on the Great Depression in Canada and the United States}

This section presents some macroeconomic data on the Canadian and U.S. economies during the Great Depression. We establish two main points in this section. First, Canada experienced a decline in output between 1929 and 1939 that was large and quantitatively very similar to that of the United States. Second, in contrast to the United States, Canadian total factor productivity (TFP) was well below trend throughout 1929-39.

We use the neoclassical growth model to organize the data. As a result, we look at per-adult variables. Unless otherwise stated, all data are divided by the number of people older than 14 for Canada and older than 16 for the United States.

We detrend all variables that grow at the same rate as output in a balanced-growth path at a 2 percent yearly rate. This trend rate is close to the long-term average growth rate for both the United States and Canada. In detrending, we have taken the view that the growth in production efficiency due to increases in the stock of usable knowledge is smooth. Other things being equal, this gives rise to a yearly growth rate of gross national product (GNP) per adult of 2 percent. ${ }^{1}$

\section{Real Data}

As we can see from Table 1, the behavior of real output in the two countries was very similar. By 1933 both countries were roughly 40 percent below trend. The recovery was very protracted in both countries, with the United States recovering slightly faster than Canada. By the end of the decade, U.S. output was still 25 percent below trend, whereas Canada's was almost 30 percent below trend.

Relative to trend, consumption fell more in Canada and remained below that of the United States throughout the 1930s. Investment in Canada fell to 15 percent of its trend value by 1933 and recovered very slowly in both countries (remaining roughly 50 percent below trend in 1939). Government purchases in the two countries followed a similar pattern during the downturn, before diverging in the late 1930s when U.S. government spending 
Table 1. Detrended levels of real output and its components, 1929-39

\begin{tabular}{lrrrrrr}
\hline & \multicolumn{2}{c}{ GNP } & \multicolumn{2}{c}{ Consumption } & \multicolumn{2}{c}{ Investment } \\
\hline Year & \multicolumn{1}{c}{ Can } & \multicolumn{1}{c}{ US } & \multicolumn{1}{c}{ Can } & \multicolumn{1}{c}{ US } & Can & US \\
\hline 1929 & 100.0 & 100.0 & 100.0 & 100.0 & 100.0 & 100.0 \\
1930 & 91.6 & 87.7 & 93.0 & 89.7 & 85.4 & 69.2 \\
1931 & 77.0 & 79.7 & 82.6 & 83.8 & 50.9 & 46.1 \\
1932 & 66.5 & 65.9 & 74.3 & 74.2 & 25.2 & 22.2 \\
1933 & 59.6 & 62.0 & 68.1 & 70.4 & 15.4 & 21.8 \\
1934 & 64.5 & 65.3 & 69.1 & 70.5 & 29.1 & 27.9 \\
1935 & 67.1 & 71.5 & 69.7 & 71.9 & 33.7 & 41.7 \\
1936 & 67.5 & 76.4 & 69.1 & 76.2 & 29.1 & 52.6 \\
1937 & 71.8 & 80.0 & 71.2 & 76.5 & 45.5 & 59.5 \\
1938 & 69.7 & 73.2 & 68.8 & 72.7 & 44.5 & 38.6 \\
1939 & 72.4 & 76.1 & 68.6 & 73.8 & 54.3 & 49.0 \\
\hline & & & & & & Imports \\
\hline Year & Can & US & Can & US & Can & US \\
\hline 1929 & 100.0 & 100.0 & 100.0 & 100.0 & 100.0 & 100.0 \\
1930 & 105.3 & 105.1 & 77.4 & 85.2 & 82.0 & 84.9 \\
1931 & 110.6 & 105.3 & 59.2 & 70.5 & 59.1 & 72.4 \\
1932 & 107.7 & 97.2 & 52.5 & 54.4 & 49.6 & 58.0 \\
1933 & 87.7 & 91.5 & 52.7 & 52.7 & 44.9 & 60.7 \\
1934 & 88.9 & 100.8 & 62.0 & 52.7 & 49.0 & 58.1 \\
1935 & 90.3 & 99.8 & 66.9 & 53.6 & 50.6 & 69.1 \\
1936 & 85.8 & 113.5 & 78.2 & 55.0 & 55.0 & 71.7 \\
1937 & 84.5 & 105.8 & 82.0 & 64.1 & 61.7 & 78.0 \\
1938 & 92.5 & 111.5 & 67.4 & 62.5 & 52.9 & 58.3 \\
1939 & 95.5 & 112.3 & 70.3 & 61.4 & 54.5 & 61.3 \\
\hline
\end{tabular}

Sources: Canadian data from Historical Statistics of Canada, series F1-13. U.S. data for GNP from Kendrick 1961, and for different components, data from Cole and Ohanian 1999.

remained above trend, whereas in Canada it fluctuated about trend.

Having looked at the product side, we now turn to the input side. We first calculate TFP, the part of output growth that cannot be attributed to input growth. We do this using the following functional form for the production function:

$$
\text { (1) } Y_{t}=A_{t} K_{t}^{\theta} H_{t}^{1-\theta}
$$

Henceforth, capital letters denote aggregate variables and lowercase letters denote household variables. $Y$ is aggregate output, ${ }^{2} A$ is the TFP factor, $K$ is 
aggregate capital, and $H$ is aggregate hours.

Given values for $\left\{Y_{t}, K_{t}, H_{t}\right\}_{t=1929}^{1939}$ and $\theta$, we can compute $\left\{A_{t}\right\}_{t=1929}^{1939}$. The parameter $\theta$ is the share of product that accrues to factor payments to capital. From the countries' national accounts we get $\theta_{\text {CAN }}=0.3$ and $\theta_{\text {U.S. }}=0.33$.

Table 2 presents the computed series. ${ }^{3}$ Notice that TFP in the United States (TFP US) recovers much faster than in Canada (TFP Can), and it is back to trend by the end of the decade. This pattern is the same for output per hour. Two questions emerge right away: Why did TFP fall so much in both countries? Why did it not recover in Canada? We return to these questions later in the paper.

We are aware that what is presented above is not TFP, but measured TFP. Measured TFP may differ from actual TFP for a number of reasons. One major issue is factor mismeasurement. In terms of capital, there is the issue of capacity utilization. In terms of labor, there is evidence that the reduction in employment was much more severe for unskilled than for skilled workers. We use Ohanian's (2001) estimates for the United States for the magnitude of these factors and recompute TFP. We find that these two factors roughly cancel each other, so that measured TFP is almost unchanged.

Another measurement question relates to what Bernanke and Parkinson (1991), among others, term labor hoarding. However, ten years seems too long a period for this argument to make sense.

Finally, there is the issue of sectoral compositional effects. We could only compute TFP for manufacturing. Manufacturing TFP is similar to aggregate TFP.

The measured TFP is completely determined by the path of the inputs. So we now look at the inputs.

Table 2 reports the capital stock for both countries (K Can and K US). The most important feature regarding the capital stock is that it declines more in Canada than it does in the United States. This is not due to higher depreciation and is in contrast to the investment figures in Table 1.

This means there are problems with the capital stock data. Do they affect the qualitative results in terms of the measured TFP? We think not. If anything, Canada's capital stock declined by less than that reported in Table 2. This suggests that adjusting for possible measurement errors in the capital stock would imply that TFP in Canada was even lower than reported.

Table 2 also compares total hours worked for the two countries ( $\mathrm{H} \mathrm{Can}$ and H US). Total hours is the product of the number of people employed and average hours worked. The series for Canada was computed using average hours for the nonagricultural sector, since a series for the whole economy (including agriculture) was not available. This is likely to lead us to overestimate the fall in labor input in Canada, as agricultural hours in the United States (and most probably in Canada) fell by less than nonagricultural hours. 
Table 2. Detrended inputs, 1929-39

\begin{tabular}{lcccccc}
\hline Year & 1929 & 1930 & 1931 & 1932 & 1933 & 1934 \\
\hline TFP Can & 100 & 98.28 & 89.58 & 86.96 & 82.26 & 83.72 \\
TFP US & 100 & 93.27 & 91.15 & 83.34 & 80.35 & 86.91 \\
K Can & 100 & 96.93 & 92.43 & 86.68 & 80.95 & 76.21 \\
K US & 100 & 98.55 & 96.16 & 92.23 & 87.27 & 82.64 \\
H Can & 100 & 91.70 & 83.32 & 72.70 & 69.18 & 77.42 \\
H US & 100 & 91.92 & 83.57 & 73.41 & 72.62 & 71.73 \\
\hline Year & 1935 & 1936 & 1937 & 1938 & 1939 & \\
\hline TFP Can & 86.83 & 86.60 & 88.45 & 88.40 & 92.75 & \\
TFP US & 93.89 & 96.38 & 99.63 & 97.33 & 100.10 & \\
K Can & 72.38 & 68.87 & 66.20 & 63.85 & 62.04 & \\
K US & 79.26 & 76.61 & 74.97 & 73.11 & 71.05 & \\
H Can & 79.52 & 82.43 & 88.66 & 86.36 & 86.19 & \\
H US & 74.72 & 80.63 & 83.03 & 76.25 & 78.68 & \\
\hline
\end{tabular}

Sources: Canadian capital data from Brown 1965, p.199, series 5. U.S. capital data from Kendrick 1961, Table A-XV. U.S. hours data from Kendrick 1961, Table A-X. Canadian hours data is series C -51 from Urquhart 1965, multiplied by average hours worked in nonagriculture, series D-409.

The main difference in measured TFP lies in the employment data. During the recovery period, total hours in Canada recovered more than they did in the United States. The question about the lack of recovery of TFP in Canada relative to the United States can now be posed as, Why did total hours recover faster in Canada than in the United States?

We now compare the private nonagricultural sectors in the two countries. This is an interesting disaggregation for several reasons. First, aggregate employment and output figures were influenced by different government policies toward public works and relief spending. ${ }^{4}$ Second, agriculture was hit by identifiable weather shocks in both countries. Also, the agricultural sector is a relatively small fraction of gross domestic product (GDP). ${ }^{5}$

As Table 1 documents, U.S. government output increased more relative to trend than Canadian government output. A large part of the difference in government expenditure can be attributed to different government policies toward providing unemployment relief. In the United States, the government relied much more heavily upon make-work projects (government relief projects) than in Canada. The fraction of the workforce employed by the government doubled in the United States while increasing by less than 50 percent in Canada. The increase in U.S. government employment was mainly due to public works, as nearly 7 percent of U.S. employment in the late 1930s was in relief projects. Relief workers were never more than 1.5 
percent of the total workforce in Canada.

Table 3 reports TFP for the private nonagricultural sector. The calculation method and the shares used were the same as for aggregate TFP. We also use the same series for capital as before. We assume that the private nonagricultural sector benefits from the services of government-owned capital. Total hours in Canada equal the product of employment in the private nonagricultural sector and average hours in nonagriculture. Total hours for the United States are from Kendrick 1961.

Table 3. Detrended private nonagricultural TFP, 1929-39

\begin{tabular}{lcccccc}
\hline Year & 1929 & 1930 & 1931 & 1932 & 1933 & 1934 \\
\hline Canada & 100 & 99.32 & 92.43 & 92.36 & 88.34 & 85.23 \\
United States & 100 & 93.56 & 88.72 & 82.17 & 79.79 & 87.75 \\
\hline Year & 1935 & 1936 & 1937 & 1938 & 1939 & \\
\hline Canada & 87.03 & 88.60 & 88.30 & 88.75 & 93.52 & \\
United States & 90.00 & 97.43 & 94.59 & 94.26 & 96.49 & \\
\hline
\end{tabular}

Source: Total hours for United States from Kendrick 1961.

In Canada, TFP in the nonagricultural sector is very similar to aggregate TFP. This performance matches with the observation that the agricultural sector was both hit by weather shocks and bore the brunt of the terms-of-trade shocks, as agricultural products (especially wheat) were Canada's largest export good.

But U.S. TFP in the nonagricultural sector behaved differently from aggregate TFP during the recovery period, since it stopped recovering in 1936, whereas aggregate TFP recovered continuously and was back to trend by 1937 . This, we claim, is a major difference between the Canadian and American experiences in the Great Depression.

The comparison of the private nonagricultural sectors reinforces our earlier conclusion that the two countries look very similar during the downturn (1929-33). However, this sectoral breakdown provides new insights into the recovery period. It suggests that in the United States, something happened around 1936 that induced a decrease in productivity. In Canada, the data reinforce the aggregate data - namely, that productivity did not recover relative to trend during the Great Depression.

\section{Nominal Data}

Given that much research on the Great Depression has focused on the role of monetary shocks, we present data on nominal variables that are central to monetary business cycle theory. As Tables 4 and 5 show, the onset of the 
Great Depression coincided with a decline in money supply and price levels of approximately 20 percent in both Canada and the United States. This deflation was accompanied by a decline in nominal interest rates, although real ex post rates were high by historical standards.

Table 4. Nominal money, prices, and interest rates in Canada, 1929-39

\begin{tabular}{lrrrccc}
\hline Year & $\begin{array}{c}\text { Monetary } \\
\text { base }\end{array}$ & M1 & $\begin{array}{c}\text { Price } \\
\text { level }\end{array}$ & $\begin{array}{c}\text { Three-month } \\
\text { T-bill }\end{array}$ & $\begin{array}{c}\text { Short-term } \\
\text { dom. bonds }\end{array}$ & $\begin{array}{c}\text { Comm. } \\
\text { paper }\end{array}$ \\
\hline 1929 & 100.00 & 100.00 & 100.00 & - & 5.34 & 5.31 \\
1930 & 88.48 & 89.65 & 97.52 & - & 4.87 & 5.28 \\
1931 & 79.34 & 83.16 & 91.46 & - & 4.43 & 5.64 \\
1932 & 78.06 & 72.44 & 82.92 & - & 5.08 & 6.60 \\
1933 & 77.50 & 70.95 & 81.54 & - & 4.15 & 6.49 \\
1934 & 78.10 & 73.19 & 82.64 & 2.830 & 2.91 & 5.27 \\
1935 & 85.85 & 80.00 & 82.92 & 1.249 & 2.29 & 4.76 \\
1936 & 93.04 & 84.62 & 85.67 & 0.753 & 1.61 & 4.12 \\
1937 & 101.96 & 93.63 & 87.88 & 0.763 & 1.93 & 3.95 \\
1938 & 108.09 & 92.77 & 87.88 & 0.676 & - & - \\
1939 & 116.59 & 99.08 & 87.05 & 0.808 & - & - \\
\hline
\end{tabular}

Sources: Monetary data from Metcalfe, Redish, and Shearer 1996, and GNE deflator (price level) from Historical Statistics of Canada. Three-month T-bill rate from Historical Statistics of Canada (H588-603). Short-term dominion bonds and corporate paper rate from Nixon 1937.

Table 5. Nominal money, prices, and interest rates in U.S., 1929-39

\begin{tabular}{lrrrcc}
\hline Year & $\begin{array}{c}\text { Monetary } \\
\text { base }\end{array}$ & \multicolumn{1}{c}{ M1 } & $\begin{array}{c}\text { Price } \\
\text { level }\end{array}$ & $\begin{array}{c}\text { Three-month } \\
\text { T-bill }\end{array}$ & $\begin{array}{c}\text { Comm. } \\
\text { paper }\end{array}$ \\
\hline 1929 & 100.0 & 100.0 & 100.0 & 4.4 & 6.1 \\
1930 & 95.9 & 94.4 & 97.0 & 2.2 & 4.3 \\
1931 & 98.7 & 85.6 & 88.1 & 1.2 & 2.6 \\
1932 & 104.3 & 74.5 & 78.4 & .8 & 2.7 \\
1933 & 108.9 & 69.9 & 76.7 & .3 & 1.7 \\
1934 & 119.8 & 78.0 & 83.2 & .3 & 2.0 \\
1935 & 139.2 & 91.0 & 84.8 & .2 & .8 \\
1936 & 157.2 & 102.1 & 85.2 & .1 & .8 \\
1937 & 168.5 & 102.9 & 89.4 & .5 & .9 \\
1938 & 181.5 & 102.2 & 87.2 & .1 & .8 \\
1939 & 215.5 & 113.7 & 86.6 & .0 & .8 \\
\hline
\end{tabular}

Source: Cole and Ohanian 1999, Table 8. 
A cross-country comparison of interest rates is limited by the fact that a market in short-term government securities in Canada did not exist before 1934. The available data suggest that nominal interest rate spreads increased from 1930 to 1932 before narrowing. Short-term interest rates on government bonds did not fall as quickly as American short-term rates did. This increase in the interest rate spread from 1930 to 1932 appears to be linked to differences in monetary policy.

Canada was the first country to leave the gold standard, suspending gold shipments in January 1929 (Bordo and Redish 1990). Despite the suspension of convertibility, the Canadian government took steps to prevent depreciation of the dollar, motivated in part by a wish to maintain access to American capital markets to refinance Dominion debt (Shearer and Clark 1984). As a result, the government maintained the advance rate at its 1928 level throughout 1930, despite the fall in world rates. This policy was ultimately abandoned in 1931. Despite this, the Canadian dollar did depreciate relative to the U.S. dollar by approximately 15 percent between 1929 and 1931, before recovering to its 1929 level in 1935.

We suspect that the data reported dramatically overstate the difference in commercial paper rates in the late 1930s. Neufeld (1972) reports the commercial paper rate compiled by Moody's for Canada and the United States. His data suggest that while the spread between Canadian and American corporate paper widened from 1930 to 1932, it then dramatically narrowed and remained under 1 percent from 1934 to 1939.

The data suggest that while monetary shocks may help explain the 1929-33 downturn, it is unlikely that they played a significant role in the protracted recovery from 1934 to 1939. In both countries, the deflation ended by 1933 , and both nominal and real interest rates remained low by historical standards.

\section{Summary}

We view the different behavior of TFP (together with the behavior of the labor input discussed below) as the main difference in the experiences of the two countries during the recovery period. Both Canadian and U.S. TFP fell roughly 20 percent relative to trend from 1929 to 1933, but unlike U.S. TFP, Canadian TFP was not back to trend by the end of the decade.

This contrasts with the similarities in per capita GNP. In both countries it fell 40 percent relative to trend from 1929 to 1933, and its recovery was very protracted. Finally, both prices and money aggregates fell considerably from 1929 to 1933 but had recovered by the end of the decade.

In the remainder of the paper, we use theory and data to assess different explanations of the Great Depression in Canada. 


\section{How Important Were TFP Shocks?}

In this section, we ask how much of the Great Depression can be explained by measured TFP. In undertaking this experiment, we take measured productivity as exogenous and feed this series into the standard stochastic growth model.

We conclude that the decline in measured TFP in Canada can account for over half of the decline and does a very good job of accounting for the protracted recovery. The TFP story can also account for 70 percent of the decline in U.S. per-adult output, but cannot account for the slow recovery.

\section{Model}

The production function is equation (1). To complete the description of technology, the law of motion of capital is

$$
K_{t+1}=(1-\delta) K_{t}+X_{t},
$$

where $\delta$ is the depreciation rate and $X$ is investment. The process for the stochastic technological shock is

$$
A_{t+1}=1-\psi+\psi A_{t}+\varepsilon_{t+1},
$$

where $\varepsilon$ is independently and identically distributed with mean zero and variance $\sigma^{2}$.

Preferences are defined over consumption and leisure, and are represented by

(4) $E_{0} \sum_{t=0}^{\infty} \beta^{t}(1+\eta)^{t}\left[\log \left(c_{t}\right)+\chi \log \left(1-h_{t}\right)\right]$,

where $h$ is time devoted to market activities and $\eta$ is the population growth rate.

We calibrate the model economy by choosing parameters in such a way that the balanced-growth path of the model economy matches certain steadystate features of the measured economies (see Cooley and Prescott 1995). All parameter values are reported in Table 6 .

Table 6. Calibration

\begin{tabular}{lcccccccc}
\hline & \multicolumn{8}{c}{ Parameters } \\
\cline { 2 - 9 } & $\theta$ & $\beta$ & $\chi$ & $\delta$ & $\gamma$ & $\eta$ & $\psi$ & $\sigma$ \\
\hline Canada & 0.30 & 0.96 & 1.70 & 0.05 & 0.02 & 0.02 & 0.9 & 0.017 \\
United States & 0.33 & 0.96 & 1.66 & 0.05 & 0.02 & 0.01 & 0.9 & 0.017 \\
\hline
\end{tabular}


The depreciation rate is set to match an investment-to-capital ratio of 0.09 for Canada and 0.08 for the United States. We choose $\beta$ to match a capitaloutput ratio of 2.6 in Canada and 2.8 in the United States. We choose $\chi$ to match the fact that households dedicate one-third of their time to market activities. The growth rate of real per capita output is $\gamma$, which we take to be 2 percent for both countries. The population growth rate $\eta$ is 2 percent for Canada and 1 percent for the United States. Given the long-run similarities between measured TFP in the two countries, we follow Cole and Ohanian's 1999 estimates and set $\psi_{\text {CAN }}=\psi_{\text {U.S. }}=0.9$ and $\sigma_{\text {CAN }}=\sigma_{\text {U.S. }}=0.017$.

The optimal decision functions are computed using a linear quadratic solution method. Given the capital stock in 1929, which we assume to be on a balanced-growth path, we feed in the measured TFP series for each country from Table 2 and obtain paths for all the variables in the model.

\section{Findings}

The results are in Figures 1 and 2. The fall in measured TFP can account for over half of the fall in output up to 1933 in Canada and approximately 70 percent in the United States. The technology shock story qualitatively matches the Canadian experience. The model predicts a faster recovery in the United States than actually occurred. Given the fast recovery in TFP, the model predicts an equally fast recovery in inputs. In reality, this recovery in inputs is very protracted, as can be seen from Table 2 . The model also predicts a faster recovery for market hours in the United States than in Canada.

From this section we obtain one finding and two puzzles. The finding is that measured TFP in Canada can account for over half of the decline and does a very good job of accounting for the protracted recovery. This leads us to conclude that any explanation for the Great Depression in Canada should be consistent with the TFP behavior. Two puzzles remain: First, why did TFP decline so much in both countries? Second, why did TFP not recover in Canada although it recovered in the United States?

\section{How Important Was Deflation?}

Many economists have argued that money and banking caused the Great Depression. In this section, we evaluate the effect of monetary shocks in Canada. We follow recent work by Cole and Ohanian (2000) for the United States and focus our attention on four monetary transmission mechanisms. The first two are the most common stories for financial factors: (a) debt deflation and (b) bank failures. The remaining two work via labor markets and are (c) surprise deflation and (d) imperfectly flexible wages.

Our conclusion is that money and banking shocks can account for a small part of the downturn and play an insignificant role in the slow recovery. The 
Figure 1. Effect of TFP shocks on Canadian output

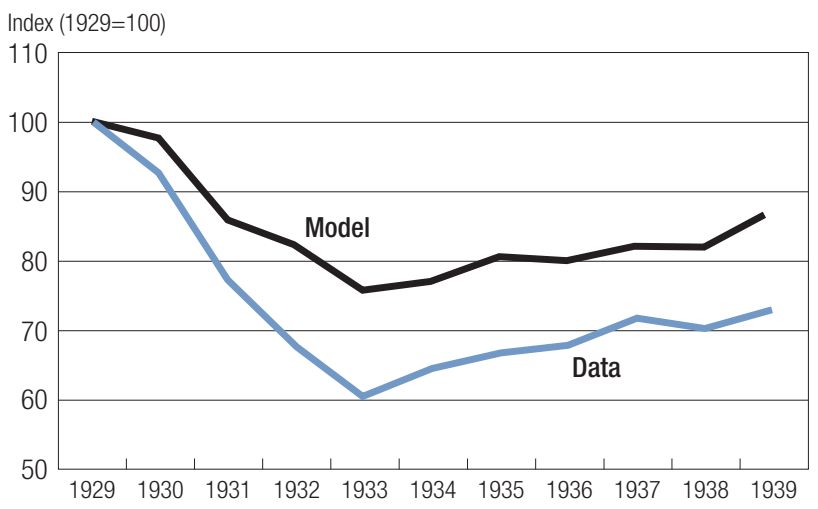

Figure 2. Effect of TFP shocks on U.S. output

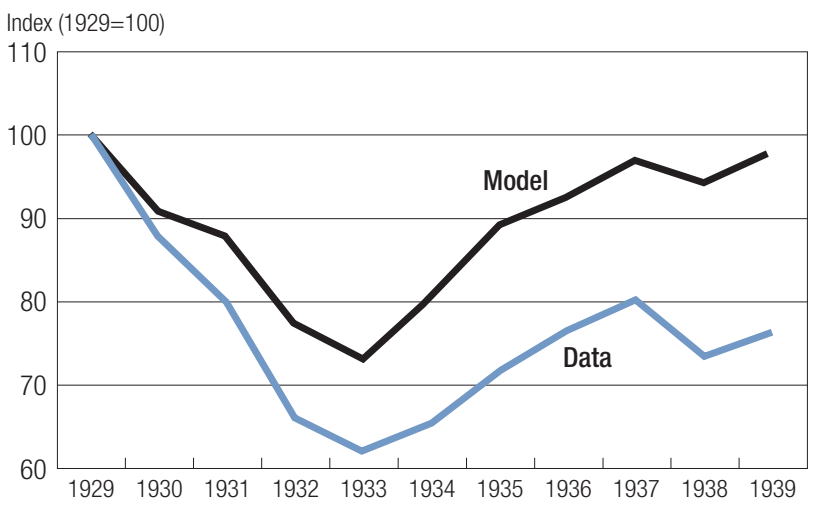

insignificant role played by financial factors is not surprising, as Haubrich (1990) provides strong evidence that they did not matter. Our results lend further weight to his conclusion and provide some interesting parallels with the analysis of Cole and Ohanian (2000) for the United States.

We devote the greatest attention to the labor market transmission mechanisms, particularly the imperfectly flexible wages story, for two reasons. First, to our knowledge, this story has not been subject to a careful evaluation for Canada. Second, this transmission mechanism has figured prominently in papers arguing that money and banking shocks played a key role in the Great Depression (Bordo, Erceg, and Evans 1997; Bernanke 1995). Our conclusion is that imperfectly flexible wages may play a small role in the downturn, but 
they play no role in explaining the slow recovery.

A key argument against the money and banking stories that we emphasize is a consistency requirement. Cole and Ohanian (2000) point out that monetary explanations of the Great Depression in the United States face the problem of explaining why the deflation of 1920-22 was associated with a short depression. This leads them to argue that any transmission mechanism must be consistent with both the deflation of 1929-33 and the (comparable) deflation of 1920-22.

Table 7 shows that Canada and the United States experienced similar deflations in 1920-22 and 1929-33. In both countries, output fell much more between 1929 and 1933 than between 1920 and 1922. Paraphrasing Cole and Ohanian (2000), if the 19 percent deflation caused the Great Depression in Canada, why did the 27 percent deflation of 1920-22 not cause a major depression as well? ${ }^{6}$

\section{Table 7. Comparing 1920-22 and 1929-33}

\begin{tabular}{lrrrr}
\hline Year & $Y$ Can & $P$ Can & $Y$ US & $P$ US \\
\hline 1920 & 100.00 & 100.00 & 100.0 & 100.0 \\
1921 & 85.71 & 84.58 & 93.9 & 85.2 \\
1922 & 94.77 & 73.12 & 96.2 & 80.6 \\
\hline 1929 & 100.0 & 100.0 & 100.0 & 100.0 \\
1930 & 91.6 & 97.5 & 86.9 & 97.5 \\
1931 & 77.0 & 91.5 & 77.6 & 88.5 \\
1932 & 66.5 & 82.9 & 64.0 & 79.5 \\
1933 & 59.6 & 81.5 & 60.9 & 77.5 \\
\hline
\end{tabular}

Sources: U.S. data from Cole and Ohanian 2000. Canadian data from Urquhart 1965,1993. Note: $Y$ is GNP per capita and $P$ is the GNP deflator. The U.S. data are from Cole and Ohanian 2000. The Canadian data are from Urquhart 1965, 1993, except for the price index for 1920-22, which is series "New A" from Altman 1992. All real data are detrended.

\section{Credit Markets}

We consider two alternative channels via which deflation could have helped cause the Great Depression through credit market disruption. The first is debt deflation, and the second is that financial crisis may have disrupted intermediation.

The debt deflation view of the Great Depression asserts that deflation and high private debt levels contributed to the Great Depression by reducing borrower wealth and constraining lending. Haubrich (1990) argues that the debt crisis was much less severe in Canada than in the United States. He argues that there is little evidence to suggest that the debt crisis caused the 
Great Depression in Canada.

Comparing the 1920s with the 1930s supports Haubrich's (1990) conclusion. If Canada experienced a debt deflation crisis, then business failures should have increased. Table 8 reports commercial failures in both countries. The Canadian series includes bankruptcies, insolvencies under provincial company acts, and proceedings such as bulk sales and tariff sales, which led to creditor loss. The American failure data include any business that was involved in court procedures or voluntary action that probably ended in creditor loss.

What is striking is that the number of commercial failures is not very high during the Great Depression. Indeed, while commercial failures in Canada more than tripled between 1920 and 1922, they increased by less than 20 percent between 1929 and 1932 before plunging to their lowest levels since 1920 in 1934. The American data also show a similar pattern. However, failures in the United States increased more than in Canada between 1929 and 1932. This suggests that the debt crisis story is not a good candidate to explain the Great Depression in Canada.

A variation on the debt crisis story that may apply to Canada is the role of external debt. Canada had considerable borrowing from abroad prior to the Great Depression. There are two problems with this story. First, as noted

Table 8. Commercial failures, $1920-25$ and 1929-35

\begin{tabular}{lccccc}
\hline & \multicolumn{2}{c}{ Canada } & & \multicolumn{2}{c}{ United States } \\
\cline { 2 - 3 } Year & $\begin{array}{c}\text { Number of } \\
\text { failures }\end{array}$ & $\begin{array}{c}\text { Liability } \\
\text { (thousands) }\end{array}$ & & $\begin{array}{c}\text { Number of } \\
\text { failures }\end{array}$ & $\begin{array}{c}\text { Liability } \\
\text { (millions) }\end{array}$ \\
\hline 1920 & 1,078 & 26,494 & & - & - \\
1921 & 2,451 & 73,299 & & 19,652 & 627 \\
1922 & 3,695 & 78,069 & & 23,676 & 624 \\
1923 & 3,247 & 65,810 & & 18,718 & 539 \\
1924 & 2,474 & 64,531 & & 20,615 & 543 \\
1925 & 2,371 & 45,768 & & 21,214 & 444 \\
\hline 1929 & 2,310 & 44,441 & & 22,909 & 483 \\
1930 & 2,741 & 57,191 & & 26,355 & 668 \\
1931 & 2,563 & 52,987 & & 28,285 & 736 \\
1932 & 2,938 & 56,631 & & 31,822 & 928 \\
1933 & 2,344 & 29,251 & & 19,859 & 458 \\
1934 & 1,627 & 20,728 & & 12,091 & 334 \\
1935 & 1,402 & 14,542 & & 12,244 & 311 \\
\hline
\end{tabular}

Sources: Canadian data from Historical Statistics of Canada (Y215-216). U.S. data from Historical Statistics of the United States, 2, V20-30. 
above, there was a decline in failures during this period. Second, the risk premium on Dominion bonds sold abroad - primarily in the United States - did not significantly increase during the 1930s. This suggests that investors did not view Canada as likely to default and lends further credence to the view that there was no external debt crisis.

A common view is that banking crisis played a significant role in transforming the 1929 downturn into the Great Depression. For example, Bernanke $(1983,262)$ states that "the financial crisis of 1930-33 affected the macroeconomy by reducing the quantity of financial services, primarily credit intermediation." As has been pointed out by numerous authors, however, Canada did not experience any bank failures. While the number of branches did fall, Haubrich (1990) finds no evidence that this impacted the level of economic activity. Indeed, Haubrich concludes that if monetary shocks mattered in the United States, it must have been because of the financial crisis.

\section{Labor Markets}

We consider two alternative channels via which deflation could have helped cause the Great Depression through labor market disruption: the surprise deflation story and the sticky wage story.

The surprise deflation story of Lucas and Rapping (1969) argues that the Great Depression was severe because it was unexpected. Cole and Ohanian (2000) point out that for this story to work, we should observe low nominal interest rates in the 1920s and high nominal and ex post real interest rates in the 1930s.

Interest rate data for both countries are reported in Table 9. Real interest rates are the nominal interest rates minus the percentage change in the annual GNP deflator. We report long-term Dominion bond yields because short-term

\section{Table 9. Nominal and ex post real interest rates in Canada and the U.S., $1920-22$ and $1930-33$}

\begin{tabular}{lcccccccc}
\hline Years & 1921 & 1922 & Avg. & 1930 & 1931 & 1932 & 1933 & Avg. \\
\hline $\begin{array}{l}\text { U.S. Treasury notes } \\
\quad \text { (nom.) }\end{array}$ & 4.83 & 3.47 & 4.35 & 2.23 & 1.15 & 0.78 & 0.26 & 1.10 \\
$\begin{array}{l}\text { U.S. Treasury bills } \\
\quad 1 \text { (real) }\end{array}$ & 19.63 & 8.87 & 14.25 & 4.73 & 10.38 & 10.95 & 2.78 & 7.21 \\
$\begin{array}{l}\text { Long-term } \\
\quad \text { Dominion (nom.) }\end{array}$ & 5.99 & 5.41 & 5.70 & 4.73 & 4.55 & 5.12 & 4.60 & 4.75 \\
$\begin{array}{l}\text { Long-term } \\
\quad \text { Dominion (real) }\end{array}$ & 16.01 & 14.70 & 15.36 & 7.23 & 10.76 & 14.46 & 6.26 & 9.68 \\
\hline
\end{tabular}


Treasury bill yields are not available until 1934. The Canadian data match the U.S. data - suggesting that the 1930s deflation was more predictable than the 1920 s deflation. This leads us to conclude that the surprise deflation story cannot explain the Great Depression in Canada.

The last monetary story we consider is that imperfectly flexible nominal wages and deflation led to high real wages. This story assumes that the short side of the labor market dominates, so that high real wages cause firms to lower their demand for labor, leading to lower employment and output.

We find that high real wages can account for no more than a 7 percent decline in output and that predicted output is above trend by 1933. The imperfectly flexible nominal wage story also has a consistency problem, as changes in measured real wages during the Great Depression are similar to changes during the 1920-22 depression.

A number of critical issues are involved in this story. As McGrattan (1999, 2001) has pointed out, the relevant variable from the point of view of the firm is the ratio of the product price to the nominal wage rate. She finds that a key theoretical problem with standard sticky wage models is that the spread between the output price and the real wage does not vary much.

McGrattan's work also points to an important empirical issue: the price index one uses to deflate wages matters. In our study, we use the GDP deflator. There were large changes in the relative prices of different types of goods. The prices of agricultural products and other commodities fell substantially relative to other goods. Both the wholesale price index and the consumer price index (CPI) overweight commodities and agricultural products. This means that using either one as a deflator would overestimate the real wage.

Figure 3 shows undetrended real wages for the industrial sector and agriculture in Canada. The nominal wage index for the industrial sector is based on the weighted average of eight nonagricultural industries (one of which is manufacturing). These nominal wage indexes are for wage earners and are based on surveys conducted by the Dominion Bureau of Statistics (DBS) of employers. Wage earners made up approximately 70 percent of the workforce (with most of the remaining workers being farmers). The farm wage series is computed using indexes of farm wages reported in various issues of the Labor Gazette (1920-40).

Figure 3 shows an important fact: real wages differed substantially across sectors of the economy. For industrial workers, the undetrended real wage increased by only 7 percent during the decline.

The industrial real wage reported in Figure 3 may be biased by compositional effects. The reduction in employment affected unskilled workers the most. Cole and Ohanian (2000) argue that for the United States, compositional effects could cause the reported real wage to be overstated by up to 15 per- 


\section{Figure 3. Real wages in Canada}

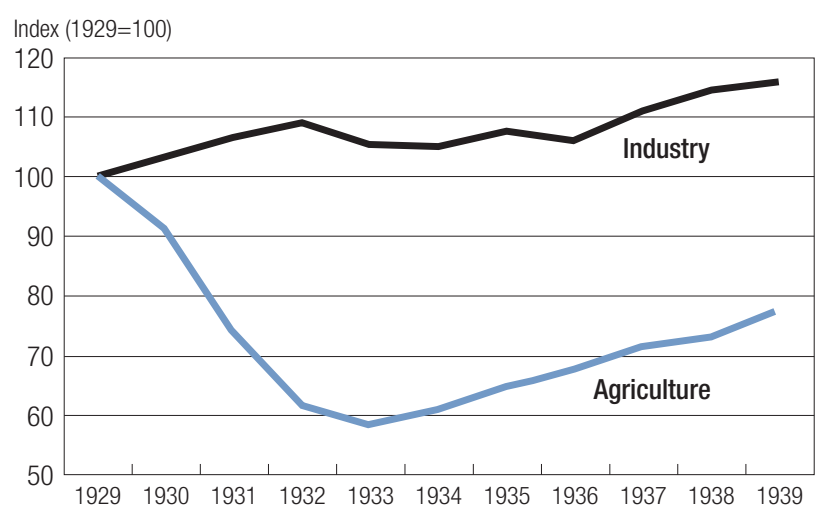

cent. Given the similarities between Canada and the United States, it could be argued that a similar figure also applies to Canada. This adjustment would imply that real wages were actually low during the Great Depression.

The real wage story also faces a consistency problem. Nominal wage inflexibility in 1920-22 appears very similar to that of 1929-39. For the United States, this fact has been established by both Cole and Ohanian (2000) and Dighe (1997). Table 10 reports detrended real wage movements in Canada and the United States. The real wage movements are very similar. Real wages in the nonagricultural sector increased slightly more over 1929-31 than they did over the 1920-22 period. Conversely, real wages in the farm sector fell more in the Great Depression than during the 1920s.

Even if one rejects the arguments presented above, the imperfectly flexible nominal wage story is quantitatively unable to explain the Great Depression. To show this, we undertake the following experiment. We modify the model economy from the previous section by assuming that the wage rate is determined exogenously and is given by the real wage in the industrial sector. The

Table 10. Detrended real wages, 1920-22 and 1929-33

\begin{tabular}{lrrrrrrrr}
\hline Year & 1920 & 1921 & 1922 & 1929 & 1930 & 1931 & 1932 & 1933 \\
\hline Can farm & 100 & 85.7 & 81.3 & 100 & 89.9 & 71.9 & 58.9 & 55.0 \\
US farm & 100 & 71.9 & 73.1 & 100 & 93.0 & 76.8 & 64.7 & 60.2 \\
Can manuf. & 100 & 103.3 & 100.1 & 100 & 101.1 & 103.7 & 105.4 & 100.6 \\
US manuf. & 100 & 101.5 & 101.2 & 100 & 102.1 & 106.8 & 106.5 & 104.2 \\
\hline
\end{tabular}


labor input is determined by the firms' first-order condition. Since we are taking a real wage series for the industrial sector, we compare the predictions of the model to the nonagricultural sector.

Figure 4 shows that the model fails to replicate the magnitude of the initial fall in Canadian output. It also completely fails to explain the lack of recovery, as it predicts that output should be above trend by 1933 .

We also repeated this experiment combining the drop in measured TFP for the nonagricultural sector and the reported real wage series. In this case, the model can account for most of the decline, but predicted output is back to trend by 1939. Comparing this to the experiment where we take only measured TFP as exogenous, we can explain 70 percent of the decline, as opposed to 60 percent. However, the predicted recovery is much faster.

We conclude that the imperfectly flexible nominal wage story cannot explain the Great Depression in Canada. Indeed, given the uncertainty about the data, it is an open question as to whether the real wage was actually "high" during the Great Depression.

\section{Summary}

Our conclusion is that money and banking shocks are unable to explain the Great Depression in Canada. Furthermore, none of these monetary explanations provides a direct channel for explaining either the observed drop in productivity or the incomplete recovery.

\section{How Important Were Competition and Labor Market Policies?}

The role of government policies in the Great Depression - particularly U.S. New Deal policies- has long been a subject of debate among economists.

Figure 4. Effect of imperfectly flexible nominal wages on Canadian output

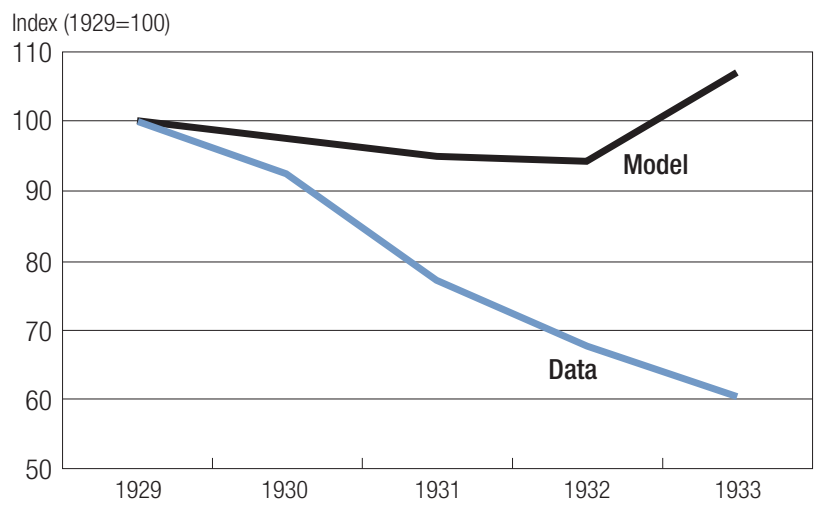


Cole and Ohanian (2004) present persuasive arguments that U.S. government competition and labor market policy played a key role in explaining the slow recovery from the Great Depression. In this section we ask two questions: What were the labor market and competition policies in Canada during the Great Depression? ${ }^{7}$ What was their impact?

What we find is surprising. Government policies were very different in Canada and the United States, particularly during the recovery period. The United States pursued a policy of reducing domestic competition and increasing wages (Cole and Ohanian 2004). There is no evidence to suggest that policies limiting competition were implemented in Canada. We also find important differences in labor market policies. Unlike the United States, Canada did not restrict hours worked or strengthen unions. Canadian policy mainly consisted of measures targeted directly at increasing wage rates. However, as discussed in the previous section, high real wages can explain a very small part of the slow recovery in Canada. This leads us to conclude that neither competition nor labor market policies can explain the Great Depression in Canada.

\section{The Bennett New Deal Legislation}

From the legislative record, one would conclude that Canada introduced policies that were very similar to those put in place by the Roosevelt administration in the United States. The Bennett government introduced Canadian New Deal legislation in 1934 and 1935, which included the main features of both the Roosevelt New Deal and British unemployment insurance schemes. Unlike in the United States, however, this legislation was not implemented before being struck down by the courts. These policies were not implemented because the Bennett government was defeated in 1935 by the Liberals, whose leader opposed these policies. ${ }^{8}$ Upon coming to power, the Liberals referred the Bennett New Deal legislation to the courts. Most substantive elements of the New Deal legislation were ruled ultra vires. As a result, these policies were never implemented.

\section{Competition Policy}

There is considerable evidence that Canadian competition policy was not relaxed during the 1930s. The number of cases dealt with under the Combines Investigation Act (the Canadian antitrust law) increased from approximately fifty during the 1923-25 period to over one hundred during the periods 1926-30 and 1931-33. In contrast, the Roosevelt administration pursued an explicit policy of facilitating cartelization by not enforcing antitrust laws. This is reflected in the nearly 50 percent fall from 1925-29 to 1930-34 in antitrust cases filed by the U.S. government. ${ }^{9}$ 
Price behavior during the 1930s also supports the view that competition policy differed across the two countries. Wholesale prices in Canada and the United States moved together during the interwar period, except for the 1933-36 period when U.S. prices rose much more quickly than Canadian prices. Romer (1999) attributes this rise in U.S. prices to the effects of the National Industrial Recovery Act (NIRA). This suggests that competition in Canada was less restrained by government policy during this period.

\section{Labor Market Policy}

In both countries, labor market policy attempted to increase wages. In Canada, these labor market policies primarily took the form of provincial governments' minimum wage schedules. These governments put very few restrictions on hours worked per worker and did not significantly change labor legislation. In sharp contrast, the Roosevelt government both limited hours worked per worker and increased the bargaining position of unions relative to management.

Most labor market intervention in Canada was done by provincial governments. They introduced minimum wage laws after the 1920-22 depression. These laws initially applied solely to female workers in the nonagricultural sector. These minimum wage schedules were unchanged until being superseded by other legislation in the late 1930s. In 1934, these minimum wages were extended to male workers replacing female workers. From 1935 to 1937, legislation was passed which allowed provincial governments to set minimum wage schedules by industry. Although this legislation allowed for the regulation of hours, this provision was rarely used.

Provincial government intervention likely increased nominal wages in Canada during the late 1930s. Did this policy have a large impact on the recovery? The answer is no. As discussed in the previous section, high real wages are unable to account for the slow recovery. Since labor market policy only increased wages, it cannot explain the slow recovery.

The contrast with American labor market policy is substantial. U.S. government policy not only increased nominal wages but also attempted to decrease hours worked. This policy was explicit under the NIRA (1933-35). After the NIRA was ruled unconstitutional in 1935, this policy was implicitly implemented through the National Labor Relations Act (NLRA), which strengthened the position of unions. The effect of this policy can be seen clearly in the rapid growth of union membership in the late 1930s. The fraction of unionized employees in nonagriculture nearly doubled, increasing from 14 percent in 1936 to 27 percent in 1938. There was also an increase in strikes in the mid-1930s.

Canadian government policy was very different. The influence of unions did not increase. This is reflected in the fact that the fraction of unionized 
workers did not increase (nor was there a large increase in labor unrest).

The timing suggests that U.S. labor market policy may have slowed the recovery by adversely impacting productivity. Our growth accounting exercise for the nonagricultural sector (discussed above) suggests that the recovery of TFP was abbreviated in 1936 in the United States but continued unabated in Canada. This change in U.S. TFP coincided with the strengthening of the unions and the rise in the fraction of the unionized labor force. This conjecture is consistent with anecdotal evidence that the formation of unions in the 1930s lowered productivity (see Brecher 1997, Chap. 5).

\section{Summary}

Canadian government competition and labor market policy cannot account for the Great Depression. There is no evidence to suggest that Canadian governments undertook policies to reduce domestic competition. The main effect of labor market policies was to increase nominal wages, particularly during the late 1930s. However, high real wages cannot account for the slow recovery (see previous section). Moreover, in Canada hours worked recovered to a much greater extent than in the United States, which also suggests that labor market policies in Canada were less restrictive than in the United States.

Our analysis suggests that American New Deal policies may have prolonged the Great Depression by halting the recovery in TFP. The productivity recovery in the private nonagricultural sector was arrested at precisely the time that American labor legislation strengthened unions. This suggests another way in which the NLRA may have slowed the American recovery.

\section{How Important Were Terms-of-Trade Shocks?}

In contrast to the United States, Canada had a very large trade sector with exports plus imports accounting for approximately 50 percent of GDP. In this section, we quantify the contribution of terms-of-trade shocks to the Great Depression in Canada. We first consider a simple partial equilibrium argument and then undertake a dynamic analysis using an open economy model. Our conclusion is surprising. Despite the fact that trade declined by 50 percent and only partially recovered (see Table 1), we find that terms-of-trade shocks can account for less than 5 percent of the decline in GDP.

Figure 5 shows that the onset of the Great Depression was associated with an adverse movement in Canada's terms of trade. ${ }^{10}$ This can be attributed to several factors. First, Canada was a net exporter of commodities. In particular, Canada was a major exporter of wheat, which experienced a large decline in price relative to other goods during the early 1930s. Another factor was the large increase in tariffs both in Canada and abroad. Canada increased tariff rates by 50 percent on average in 1930 in retaliation to the U.S. Smoot- 
Hawley Tariff Act and imposed a number of nontariff trade barriers. These nontariff barriers were substantial, as the Ministry of National Revenue made extensive use of its power to assign artificial valuations to Canadian imports (Brecher 1957).

One feature of Figure 5 worth noting is that there was a steeper fall in the terms of trade in Canada in 1920-22, and this did not cause a protracted depression. This suggests that the terms-of-trade shock story faces a consistency problem.

\section{Figure 5. Terms of trade in Canada}

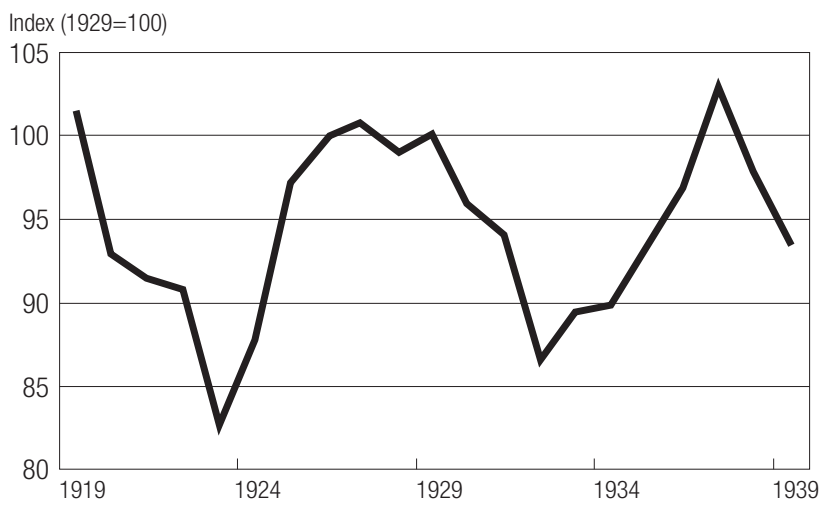

A simple back-of-the-envelope calculation suggests that trade cannot explain more than a third of the Great Depression in Canada. Suppose that a reduction in exports will lead to a one-for-one reduction in output. Exports were roughly 25 percent of Canadian GNP in 1929. By 1932 they had fallen by slightly more than half their 1929 level. If factors used in the production of exports could not be reallocated, then this could account for a decline of 13.5 percent in output at most. This is roughly one-third of the actual decline in real GNP per capita. Moreover, the fall in output that can be attributed to a decline in trade with the United States is less than half of this figure-less than 6 percent.

This calculation also casts doubt on the common notion that the United States transmitted the Great Depression to Canada via trade. While the United States was Canada's largest trading partner in 1929 (having surpassed the United Kingdom in 1927), the United States received 35 to 45 percent of Canadian exports. Furthermore, while total trade with the United States fell by more than half between 1929 and 1933, net exports to the United States increased. 
The above exercise, although illustrative, abstracts from important issues, namely the fact that domestic and imported goods can be imperfect substitutes. If this is the case, the domestic country is partially unable to substitute away from imports as their relative price increases. This lowers investment, which in turn leads to a fall in output.

We use a variation of the Backus, Kehoe, and Kydland (1995) model to quantify the effects of terms-of-trade shocks. Canada is modeled as a small, open economy that takes terms of trade as given. For the sake of consistency with the Backus et al. language, we define the terms of trade as the price of imports divided by the price of exports.

The economy is populated by an infinitely lived representative household whose preferences can be represented by (3). The home country, Canada, specializes in the production of a single good, which we call $a$. The rest of the world specializes in the production of a single good, $b$. Canada produces $a$ using a constant-returns-to-scale production function that takes as inputs domestic labor and domestic capital:

$$
a_{c, t}+a_{f, t}=Y_{c, t}=A_{t} K_{t}^{\theta} H_{t}^{1-\theta},
$$

where $\theta$ is capital's share of product and $A$ is total factor productivity. The process for $A_{t}$ is the same as defined earlier.

$Y_{c}$ is GDP in Canada. This can be consumed either in Canada $a_{c}$ or exported abroad $a_{f}$. Domestic consumption $C$ and investment $X$ are composites of the imports $b_{c}$ and the domestic good $a_{c}$ :

$$
C_{t}+X_{t}=G\left(a_{c, t}, b_{c, t}\right)
$$

where $G$ is an aggregator given by

$$
G\left(a_{c, t}, b_{c, t}\right)=\left[\omega a_{c, t}^{1-\rho}+b_{c, t}^{1-\rho}\right]^{\frac{1}{1-\rho}}
$$

where $\omega$ is the relative weight of domestic goods and the elasticity of substitution between foreign and domestic goods is given by $1 / \rho$. Capital is a nontraded good, and its law of motion is given by (2).

We assume that the world markets for both goods are perfectly competitive. The price of the foreign good is denoted by $q_{f}$ and the domestic good by $q_{c}$. The trade balance is the value of exports minus the value of imports and is given by

$$
n x_{c, t}=q_{c, t} a_{f, t}-q_{f, t} b_{c, t} .
$$


The terms of trade are given by $p_{t}=q_{f, t} / q_{c, t}$, where the process for $p_{t}$ is

$$
p_{t+1}=\varphi+\phi p_{t}+\varepsilon_{t+1}
$$

Trade is assumed to be balanced throughout, which implies $a_{f, t}=p_{t} b_{c, t} \cdot{ }^{11}$

In calibrating this model, all parameters common to the model in the section on TFP have the same value as in Table 6 . The parameter $\omega$ was calibrated to match a 25 percent steady-state share of imports in GNP. The parameters defining the terms-of-trade process were estimated using OLS (ordinary least squares) and are $\varphi=0.3$ and $\phi=0.66$. Note that because we use a linear quadratic approximation, the standard deviation of the error term plays no role.

We assume that the economy is on its balanced-growth path in 1929. The 1929 capital stock is our initial capital stock in the model. We take the terms of trade from the data (the reciprocal of Figure 5) and feed these into the computed decision functions. This gives us the predicted paths for all the variables in the economy.

We report the results for two different values of the elasticity of substitution (recall that $\rho$ is the reciprocal of the elasticity of substitution). The first case corresponds to an elasticity of substitution of 8 , and the second case to 0.8 . If the terms of trade are going to have any effect on output, it will be in the second case where the country cannot easily substitute away from imports.

Figure 6 shows our results. The results indicate that terms-of-trade shocks are unable to account for the Great Depression in Canada. In both the elastic and inelastic cases, the model predicts a decline in output of around 3 percent. However, in the elastic case, the model predicts a slightly bigger fall in trade than actually occurred, while in the inelastic case, trade falls very little.

Figure 6. Effect of terms-of-trade shocks on Canadian output

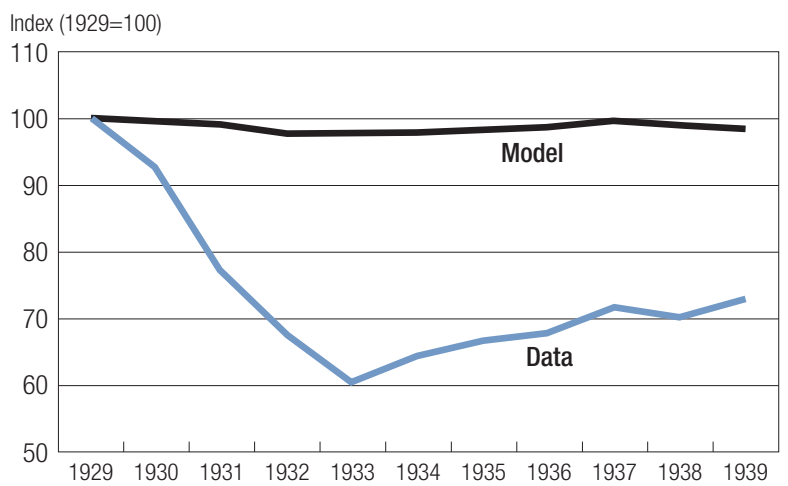


We have also repeated the above experiments using the TFP series from the data. We find that combining the two is not significantly different from using TFP shocks only.

We conclude that adding terms-of-trade shocks to the business cycle model does not significantly add to its ability to explain the Great Depression. This result is subject to some caveats. Crucini and Kahn (1996) have emphasized that a substantial part of interwar trade was in intermediate products. If the domestic and foreign intermediate products are imperfect substitutes in production, an increase in the relative price of the imported intermediate goods will affect capital accumulation and output. However, a problem with this story is that it does not provide a link between trade and the behavior of TFP, which we argue is key to understanding the Great Depression in Canada.

\section{Conclusions}

Was the Great Depression in Canada similar to the Great Depression in the United States? While the downturn (1929-33) was very similar in both countries, the recovery (1934-39) was very different. In the United States, the recovery in output was very slow despite the rapid recovery of productivity. In Canada, productivity recovered much more slowly than in the United States, while output recovered almost as quickly. Any explanation of the Great Depression must be able to account for these differences.

TFP shocks can account for a significant part of the ten-year Canadian Depression. This leads us to conclude that any successful explanation of the Great Depression must be one that involves an initial decline and a very protracted recovery in measured productivity. However, since we do not have any theory for either the decline or the lack of recovery of TFP, we view this TFP behavior as an unresolved puzzle.

Can the usual explanations of the Great Depression account for the Great Depression in Canada? Our answer to this question is no. As we show, money shocks, policy shocks, and terms-of-trade shocks cannot account for the ten-year Depression. Explanations based on these shocks fail because their effects are quantitatively too small to explain the Great Depression in Canada.

In light of our findings, future research into the Great Depression in Canada should focus on models in which changes in the level of trade affect the level of productivity. Such models are consistent with the fact that Canada's TFP and trade both declined from 1929 to 1933. Beginning in 1934, trade slowly began to recover, and so did TFP. This also matches the fact that the only large shock that hit Canada but not the United States was trade, whereas the main difference in macro performance is the behavior of productivity. 


\section{Notes}

Reprinted from Review of Economic Dynamics, Vol. 5, Pedro S. Amaral and James C. MacGee, "The Great Depression in Canada and the United States: A Neoclassical Perspective," pages 45-72, copyright 2002, with permission from Elsevier.

We are especially grateful to Tim Kehoe, Ed Prescott, Lee Ohanian, and Hal Cole for their comments and suggestions. Comments by Ben Bridgman, Ron Leung, Igor Livshits, and Manuel Santos, as well as seminar participants at the 2001 Society for Economic Dynamics meeting in Stockholm and the Minnesota Macro Workshop, are also much appreciated. Amaral acknowledges financial support from Fundação para a Ciência e Tecnologia.

1. Per capita GDP growth in Canada is actually slightly higher than the United States.

2. We used GDP from the National Income and Expenditure Accounts.

3. Note that TFP is not detrended at a rate of 2 percent but at a rate equal to $1.02^{1-\theta}$ for each country, a trend that is close to the historical averages (excluding war periods).

4. Government enterprises are included in the private sector.

5. Agricultural GDP as a fraction of total GDP averaged 6.2 percent in the United States and 10.4 percent in Canada from 1929 to 1939.

6. The two depressions were also similar in that Canada faced deteriorating terms of trade and the Canadian dollar depreciated relative to the United States by a similar amount during both depressions.

7. Amaral and MacGee (2001) provide a more detailed description of Canadian government policy.

8. King's view is reflected in his quote that Roosevelt's "mad desire to bring about State control and interference beyond all bounds made one shudder" (Struthers 1983, 105).

9. The number of antitrust cases filled is contained in the work by Cox (1981), who cites data compiled by Posner.

10. The terms of trade is the ratio of an index of Canadian prices of export goods divided by an index of Canadian prices of imported goods.

11. This is a reasonable approximation given the data.

\section{References}

Altman, Morris. 1992. Revised real Canadian GNP estimates and Canadian economic growth, 1870-1926. Review of Income and Wealth 38 (December): 455-73.

1999. New estimates of hours of work and real income in Canada from the 1880s to 1930: Long-run trends and workers' preferences. Review of Income and Wealth 45 (September): 353-72.

Amaral, Pedro, and James MacGee. 2001. Canadian government policy during the Great Depression. Manuscript. University of Minnesota. 
Backus, David; Patrick J. Kehoe; and Finn E. Kydland. 1995. International business cycles: Theory and evidence. In Frontiers of business cycle research, ed. Thomas F. Cooley, 331-56. Princeton, NJ: Princeton University Press.

Bernanke, Ben S. 1983. Nonmonetary effects of the financial crisis in the propagation of the Great Depression. American Economic Review 73 (June): 257-76.

1995. The macroeconomics of the Great Depression: A comparative approach. Journal of Money, Credit and Banking 27 (February): 1-28.

Bernanke, Ben S., and Martin L. Parkinson. 1991. Procyclical labor productivity and competing theories of the business cycle: Some evidence from interwar U.S. manufacturing industries. Journal of Political Economy 99 (June): 439-59.

Betts, Caroline M.; Michael D. Bordo; and Angela Redish. 1996. A small open economy in Depression: Lessons from Canada in the 1930s. Canadian Journal of Economics 29 (February): 1-36.

Bordo, Michael D.; Christopher J. Erceg; and Charles N. Evans. 1997. Money, sticky wages, and the Great Depression. Working Paper 6071. National Bureau of Economic Research.

Bordo, Michael D., and Angela Redish. 1990. Credible commitment and exchange rate stability: Canada's interwar experience. Canadian Journal of Economics 23 (2): 357-80.

Brecher, Irving. 1957. Monetary and fiscal thought and policy in Canada: 1919-1939. Toronto, ON: University of Toronto Press.

Brecher, Jeremy. 1997. Strike. Boston, MA: South End Press.

Brown, Tillman Merritt. 1965. Canadian economic growth. Ottawa, ON: Queen's Printer.

Cole, Harold L., and Lee E. Ohanian. 1999. The Great Depression in the United States from a neoclassical perspective. Federal Reserve Bank of Minneapolis Quarterly Review 23 (Winter): 2-24.

. 2000. Re-examining the contributions of money and banking shocks to the U.S. Great Depression. Research Department Staff Report 270. Federal Reserve Bank of Minneapolis.

2004. New deal policies and the persistence of the Great Depression: A general equilibrium analysis. Journal of Political Economy 112 (August): 779-816.

Cooley, Thomas F., and Edward C. Prescott. 1995. Economic growth and business cycles. In Frontiers of business cycle research, ed. Thomas F. Cooley, 1-38. Princeton, NJ: Princeton University Press.

Cox, Charles C. 1981. Monopoly explanations of the Great Depression and public policy towards business. In The Great Depression revisited, ed. Karl Brunner, 174-207. Rochester Studies in Economics and Policy Issues, Vol. 2. Boston: Martinus Nijhoff.

Crucini, Mario J., and James Kahn. 1996. Tariffs and aggregate economic activity: Lessons from the Great Depression. Journal of Monetary Economics 38 (December): 427-67.

Dighe, Ranjit S. 1997. Wage rigidity in the Great Depression: Truth? Consequences? Research in Economic History 17:85-134.

Haubrich, Joseph G. 1990. Nonmonetary effects of financial crises: Lessons from the Great Depression in Canada. Journal of Monetary Economics 25 (March): 223-52.

Kendrick, John W. 1961. Productivity trends in the United States. Princeton, NJ: Princeton University Press (for NBER). 
Labor Gazette. 1920-40. Department of Labor, Canada.

Lucas, Robert E., and Leonard A. Rapping. 1969. Real wages, employment, and inflation. Journal of Political Economy 77 (September-October): 721-54.

McGrattan, Ellen R. 1999. Predicting the effects of Federal Reserve policy in a sticky-price model: An analytical approach. Working Paper 598. Federal Reserve Bank of Minneapolis.

2001. Unpublished appendix to Working Paper 598 (Predicting the effects of Federal Reserve policy in a sticky-price model: An analytical approach, 1999). Federal Reserve Bank of Minneapolis.

Metcalfe, Cherie; Angela Redish; and Ronald Shearer. 1996. New estimates of the Canadian money stock: 1871-1967. Discussion Paper 96-17. University of British Columbia.

Neufeld, Edward P. 1972. The financial system of Canada. Toronto, ON: Palgrave Macmillan.

Nixon, Stanley E. 1937. Interest rates in Canada: The course of interest rates, 1929-1937. Canadian Journal of Economics and Political Science 3:421-34.

Ohanian, Lee E. 2001. Why did productivity fall so much during the Great Depression? Staff Report 285. Federal Reserve Bank of Minneapolis.

Romer, Christina D. 1999. Why did prices rise in the 1930s? Journal of Economic History 59 (March): 167-99.

Shearer, Ronald A., and Carolyn Clark. 1984. Canada and the interwar gold standard, 1920-35: Monetary policy without a central bank. In A retrospective on the classical gold standard, 1821-1931, ed. Michael D. Bordo and Anna J. Schwartz, 277-310. Chicago: University of Chicago Press.

Siklos, Pierre. 2002. Understanding the Great Depression in the United States versus Canada. In World economy and national economies in the interwar slump, ed. T. Balderston. Basingstoke: Palgrave Macmillan.

Statistics Canada. Historical statistics of Canada. http://www.statcan.ca:80/english/freepub/11516-XIE/sectiona/toc.htm.

Statistics Canada. 1988. National income and expenditure accounts: Annual estimates 1926-86. Ottawa, ON: Canadian Government Publishing Center.

Struthers, James. 1983. No fault of their own: Unemployment and the Canadian welfare state 1914-1941. Toronto, ON: University of Toronto Press.

Urquhart, Malcolm C., ed. 1965. Historical statistics of Canada. Toronto, ON: Macmillan. 1993. Gross national product, Canada, 1870-1926: The derivation of the estimates. Kingston and Montreal: McGill-Queen's University Press.

U.S. Department of Commerce. 1975. Historical statistics of the United States: Colonial times to 1970. 
